\title{
Multiplicative Dynamic Model of Technological Progress Factor Impact on Economy Sectors Innovation Development
}

\author{
Olha Prokopenko \\ Economics Department \\ Collegium Mazovia Innovation \\ University \\ Siedlce, Poland; \\ Tallinn University of Technology \\ Tallinn, Estonia \\ prokopenko.olha.w@gmail.com \\ Vitaliy Omelyanenko* \\ Institute of Industrial Economics of \\ National Academy of Sciences of \\ Ukraine \\ Kyiv, Ukraine \\ omvitaliy@gmail.com
}

\author{
Nataliia Biloshkurska \\ Department of Marketing, Management \\ and Business Management \\ Pavlo Tychyna Uman State \\ Pedagogical University \\ Uman, Ukraine \\ natasbil@gmail.com
}

Olena Garmatiuk

Department of Marketing, Management

and Business Management

Pavlo Tychyna Uman State

Pedagogical University

Uman, Ukraine

garmatiuk85@gmail.com

\author{
Mykola Biloshkurskyi \\ Department of Finance, Accounting \\ and Economic Security \\ Pavlo Tychyna Uman State \\ Pedagogical University \\ Uman, Ukraine \\ nickbrown946@gmail.com
}

\begin{abstract}
The research addresses the issues of development the active mechanisms to manage the national economy sectors innovation development taking into account their pace of technological progress and resource potential proportionality. The study is based on the idea about relative importance of different sectors of the economy in innovation terms in the process of overall economic development. The main issues and cases of different economic models of emergence and diffusion of innovations and analytical support of innovation and technological changes management through the development of integrated development strategies were considered. As key component of improved multiplicative dynamic model of $J$. Tinbergen production function the parameter of technological progress, which reflects the level of innovation development of the national economy, was considered. Based on research results Tinbergen's production function equation for the Ukrainian industry was obtained. The equation obtained is reliable and statistically significant, as it is described by high statistical estimates.
\end{abstract}

Keywords - innovation, dynamic model, priority sector, technological progress, production function

\section{INTRODUCTION}

Analytics of innovation trajectories and demand of macroeconomics in the national security context requires to manage the technological component of the economy and its innovation development, as well as the appropriate structure of innovation supply, which enables effective strategic decisions making. This is due to the fact that in the current context, numerous risks are associated with the structural backwardness of the economy in a number of parameters and increased raw material nature. This has led to a high level of import dependency of some industries, the loss of number of industries, sectors and products with high value and relevant markets. In the future, the inertia of technological backwardness and the lack of measures to develop the innovation and technological ecosystem threatens to further situation worsen.

The technological paradigm problem is in the focus of researchers began to appear from the middle of XX century, and is not yet sufficiently developed, because there is a wide range of studies of technical system itself, which are incomplete without taking into account the system context of modern innovations.

Basic methodological groundwork to evaluate the national economy innovation development under conditions of technological progress is laid by such scientists as Tinbergen J. [1], Solow R. [2], Moroney J. R. \& Ferguson C. E. [3] and others. Today, ideas regarding evaluation of either national economy innovation development in general and its definite sectors in particular, play a significant role. The Clark-Fisher model is a theoretical justification for the dynamics of relative importance of different sectors of the economy in terms of job creation in the process of overall economic development. In our study we propose to consider the innovation dimension of relative importance of different sectors.

From main points of evolutionary theory and based the green industrial dynamics analysis on author of research [4] concludes that the sectoral characteristics are important to innovations.

Research [5] deals with the role of cultural and creative industries for thr fostering the innovations and growth in wider economy. In the paper, the factors of creative economy were combined with evolutionary analysis in order to understand in which sectors the cultural and creative industries can foster innovation processes in wider economy. To consider the role of creative industries relatedness and clustering in economic growth a panel data analysis were applied. It has shown that to promote growth creative industries development the presence of high degree relatedness in other sectors is required. 
According to [6] industrial structure models allows predict employment growth and economy-wide characteristics. The findings of study [7] prove the importance of industrial structure for employment changes, economic performance and industrial development understanding.

In study [8] sector or subsystem approach to formulation of models of system dynamics was described. This approach incorporates the interaction matrix concept to assist such models formulation. A discussion of the limitations and possible alternatives to sector approach concludes the paper.

From the point of [9], regional industry structure impacts on $\mathrm{R} \& \mathrm{D}$ resources conversion into innovation products (services). The main conclusion for policy makers deals with the results of cross-level analyses of Norway. Is has shown that innovation performance from $R \& D$ investments is stronger in regions with specialized structure than in regions with diversified structure.

Within the conditions of projects hierarchical and dynamic complexities the innovation analytics tasks are significantly expanded. In the research the decision model is regarded as predictive tool with the purpose of explaining the projects dynamic behavior [10].

E.g. in research [11] two components of industry evolution (market evolution pace and technology evolution pace) were considered. This article [12] examines the technological diversity effect, capacity and knowledge flow on industrial innovation development.

According to [13] new industrial innovation policy methodology requires system industrial diversification to promote fundamental structural changes in economy through the transformative activities.

Scientists-economists have not enough studied problems of national economy sectors innovation development, taking into account compliance with technological progress and technical substitution marginal rate. Therefore the main objective of research is to develop active mechanisms to manage the Ukrainian national economy sectors innovation development taking into account their pace of technological progress and resource potential proportionality.

\section{SECTOR INNOVATION DEVELOPMENT MODELS COMPOSITION FRAMEWORK}

Numerous studies show that different economic models are characterized by different patterns of emergence and diffusion of innovations, as well as different nature of relationship between the innovation activity of companies, the results of their production and economic activity, competitiveness in domestic and foreign markets [14]. This aspect substantially complicates the solution of the following tasks, which underlie our proposed methodology: radical technological modernization of traditional sectors and scientifically-based determination of interconnected national innovation priorities, which will be consistent with motivational and resource-based organizational and economic mechanisms; review of state participation mechanisms in economy to accelerate technological modernization of the basic sectors and formation of globally competitive corporations and inter-sector high-tech complexes; implementation of digital transition by expanding the use of digital technologies in major sectors of the economy, the creation of infrastructure and the system of regulation of the IT economy, which takes on a special role in Industry 4.0 conditions; modernization of technical regulation system, creation a new standardization and certification system according to innovation economy conditions.

As part of the network effects formation, we note the potential of Quintuple Helix model, which is the framework for broader interdisciplinary analysis of medium and longterm development based on innovation. In the context of institutional dynamics, the principle of strategic orientation of innovation economic development of sectors should be noted. A stable unidirectional balance of the ways of development of economy and society with their natural environments is very important for the qualitative efficiency of further progress. The Quintuple Helix model emphasizes that the natural environment needs to be conceptualized to identify further strategies for developing innovation systems.

Thus, we believe that Quintuple Helix model allows to analyze the barriers to technology transfer and the global innovation gap, because technology is part of a general industrial structure that determines the extent to which innovation is diffused and used effectively. Among the main findings from the analysis of the Quintuple Helix model that affect the strategic aspects of development and analytical framework we can underline:

1) globalization as an expansion of the space of opportunities, alternatives and sources of information. It is manifested through the internationalization of innovation networks of different types and levels (research type, technology transfer, social, professional, industrial and social relations, etc.), as well as the dynamics of the global market.

Open Innovation are the factors of this aspect and accelerate the technological series of events, the diversity of innovation environment and systems, global partnerships and the management of knowledge chains.

2) evolution of innovation systems, which is manifested in increasing the intensity of innovation communications as a result of innovation process complexity, the diversity of communication channels. This facts result in thechansing in the innovation analytics bases.

Based on our previous research [15-16] and studies [17; 18], we propose a methodology for analytical support of innovation and technological changes management through the development of integrated development strategies within the national development strategies. This methodology is based on necessity of identifying the mechanisms based on maximizing the relationship between the technological paradigm and the cross-industry technological trajectory.

\section{MultiPliCATIVE DYNAMIC MODEL VERIFICATION}

During the evaluation of the national economy sectors innovation development there is another important requirement - consideration of compliance with technological progress and resource potential proportionality. Compliance with the requirements to the methodic provision of national economy sectors innovation development evaluation (case of Ukraine) is provided by the authors approach for multiplicative dynamic model of Tinbergen J. production function [19] application: 


$$
Q=A \cdot K^{\alpha} \cdot L^{\beta} \cdot e^{\gamma t}
$$

where $Q$ - an amount of production realization (goods, works, service) by business entities in the sector, mln UAH; $K$ - factor of the physical capital (value of total assets in the enterprises of the sector), mln UAH; $L$ - factor of the human capital (number of the workers, engaged in the sector), thousand persons; parameter $A$ - free member (numeric value of $Q$, if $\alpha=\beta=\gamma=0$ ); parameter $\alpha$ - coefficient of production realization amount elasticity by the physical capital factor (percent growth of $Q$ with increase in $K$ by $1 \%$ ); parameter $\beta$ - coefficient of production realization amount elasticity by the human capital factor (percent growth of $Q$ with increase in $L$ by $1 \%$ ), with $\beta=1-\alpha$; parameter $\gamma$ - parameter of the technological progress (coefficient of the production realization amount elasticity by the technological progress; $e$ - Euler number (base of the natural logarithm); $t$ - factor of the technological progress (serial number of the year).

Having processed the appropriate statistical information, we received the following equation of Tinbergen $J$. production function for industry in Ukraine:

$$
Q=12,692 \cdot K^{0,344} \cdot L^{0,656} \cdot e^{0,131 \cdot t}
$$

The economic interpretation of the received equation (2) is: if total assets of the industrial enterprises (physical capital) are increased by $1 \%$, the realized industrial production (goods, works, service) will be grown by $0.34 \%$; if the number of workers, engaged in industry (human capital), is increased by $1 \%$, amount of realized industrial production (goods, works, service) will be grown by $0.66 \%$. Technological progress parameter $\gamma=0.131$ in formula (2) means, that Ukrainian industry receives extra growth $+0.13 \%$ of production realization as a result of compliance with technological progress and innovation activity efficiency.

Therefore we can talk about its intensive development and extended reproduction. The received equation is accurate and statistically significant, because it is described by high statistic evaluations, particularly multiple correlation coefficient is $R=0.988$, determination coefficient $-R^{2}=0.977$, F Fisher criterion $-F=253.0$, Student's t-test $-t=23.4$.

One can conclude that human factor prevails over capital in the Ukrainian industry, that is why industrial production is more hand-operated, than automatized production, because the return on labor (human capital) far exceeds the return on physical capital. It is shown by marginal rate of technical substitution (MRTS):

$$
M R T S=-\frac{\alpha \cdot L}{\beta \cdot K}=-\frac{0,344 \cdot L}{0,656 \cdot K}=-0,524 \frac{L}{K}
$$

Formula (3) demonstrates that labor costs to compensate decreasing for 1 unit of the capital are twice as small as capital cost. It means that for Ukrainian industry saving of 1 mln of total assets is equal to extra involving of 524 engaged workers and, accordingly, saving of 1 thousand workers may be substituted by 2096 thousand UAH of physical capital. The received results prove low level of industrial production mechanization and automatization in Ukraine, but intensive development and extended reproduction.

Therefore, domination of human capital over physical capital, which is equal to larger cash alternative cost (in our case approximately $2: 1$ ), can be interpreted as its high value in the industry of Ukraine.

In order to realize the task, initial statistic and intermediate calculation data were analogically formed (see table 1-2) for each of the given economic activity, and information was statistically processed. Therefore, the period for research was three years shorter from 2005 to 2016, owing to absence of official statistic data on State Statistics Service official site for 2002-2004 [20-23].

Results of Tinbergen J. production functions modeling to receive actual values of technological progress parameter and calculations of marginal rate of technical substitution are demonstrated in the table 1 .

\begin{tabular}{|c|c|c|c|c|c|c|c|c|c|}
\hline Type of economic activity & $\boldsymbol{A}$ & $\alpha$ & $\boldsymbol{\beta}$ & $\gamma$ & MRTS & $\boldsymbol{R}$ & $t$ & $R^{2}$ & $\boldsymbol{F}$ \\
\hline 1. Agriculture, hunting and forestry & 8.733 & 0.227 & 0.773 & 0.225 & -0.293 & 0.991 & 23.4 & 0.982 & 246.8 \\
\hline 2. Construction & 46.418 & 0.113 & 0.887 & 0.153 & -0.127 & 0.979 & 15.4 & 0.959 & 106.3 \\
\hline 3. Industry & 12.692 & 0.344 & 0.656 & 0.131 & -0.523 & 0.988 & 23.4 & 0.977 & 253.0 \\
\hline 4. Education & 9.356 & 0.242 & 0.758 & 0.117 & -0.319 & 0.994 & 28.0 & 0.987 & 354.0 \\
\hline 5. Health care and social assistance & 2.527 & 0.577 & 0.423 & 0.107 & -1.361 & 0.997 & 43.1 & 0.995 & 837.0 \\
\hline $\begin{array}{l}\text { 6. Transport, warehousing, postal and courier activities, information and } \\
\text { telecommunications }\end{array}$ & 18.560 & 0.292 & 0.708 & 0.097 & -0.412 & 0.996 & 37.7 & 0.993 & 637.9 \\
\hline 7. Temporary placement and organization of food & 4.633 & 0.482 & 0.518 & 0.091 & -0.932 & 0.975 & 13.9 & 0.951 & 87.4 \\
\hline $\begin{array}{l}\text { 8. Real estate, professional, scientific and technical activities, activity in } \\
\text { the field of administrative and auxiliary service }\end{array}$ & 1.301 & 0.697 & 0.303 & 0.065 & -2.301 & 0.978 & 14.7 & 0.956 & 97.2 \\
\hline 9. Wholesale and retail trade; repair of motor vehicles and motorcycles & 2.815 & 0.923 & 0.077 & -0.034 & -12.038 & 0.985 & 18.1 & 0.970 & 147.4 \\
\hline 10. Financial and insurance activities & 138.586 & 0.333 & 0.667 & -0.040 & -0.500 & 0.639 & 2.8 & 0.408 & 3.4 \\
\hline
\end{tabular}

TABLE I. RANGING OF NATIONAL ECONOMY SECTORS IN UKRAINE BY TECHNOLOGICAL PROGRESS PARAMETER (LEVEL OF THE INNOVATION DEVELOPMENT)

Analogically let us make calculations to form Tinbergen J. production function in order to receive technological progress parameter and to find marginal rate of technical substitution for other sectors in national economy, according to [9]: agriculture, hunting and forestry; construction; wholesale and retail trade; repair of motor vehicles and motorcycles; temporary placement and organization of food; transport, warehousing, postal and courier activities, information and telecommunications; financial and insurance activities; real estate, professional, scientific \& technical activities, activity in administrative and auxiliary service field; education, healthcare and social assistance. 
Ranging of national economy sectors by technological progress parameter enables to define the most and the least innovationly developed sectors from them.

In the national economy of Ukraine three sectors agriculture, hunting and forestry (technological progress parameter $\gamma=0.225$ ), construction (technological progress parameter $\gamma=0.153$ ) and industry (technological progress parameter $\gamma=0.131$ ) are the most innovationly developed and such ones, economic activity of which corresponds technological progress. Financial and insurance activities (technological progress parameter $\gamma=-0.04$ ), wholesale and retail trade; repair of motor vehicles and motorcycles (technological progress parameter $\gamma=-0.034$ ) are the least innovational developed sectors in the national economy and such ones, which lag behind technological progress.

In order to finish analysis it is reasonable to compare the received actual values of MRTS and parameter $\gamma$ in every sector of national economy with critical values $(M R T S<-1$; $\gamma<0$ ), having formed matrix "Marginal rate of technical substitution and Technological progress parameter" based on the data of Table 1 (fig. 1).

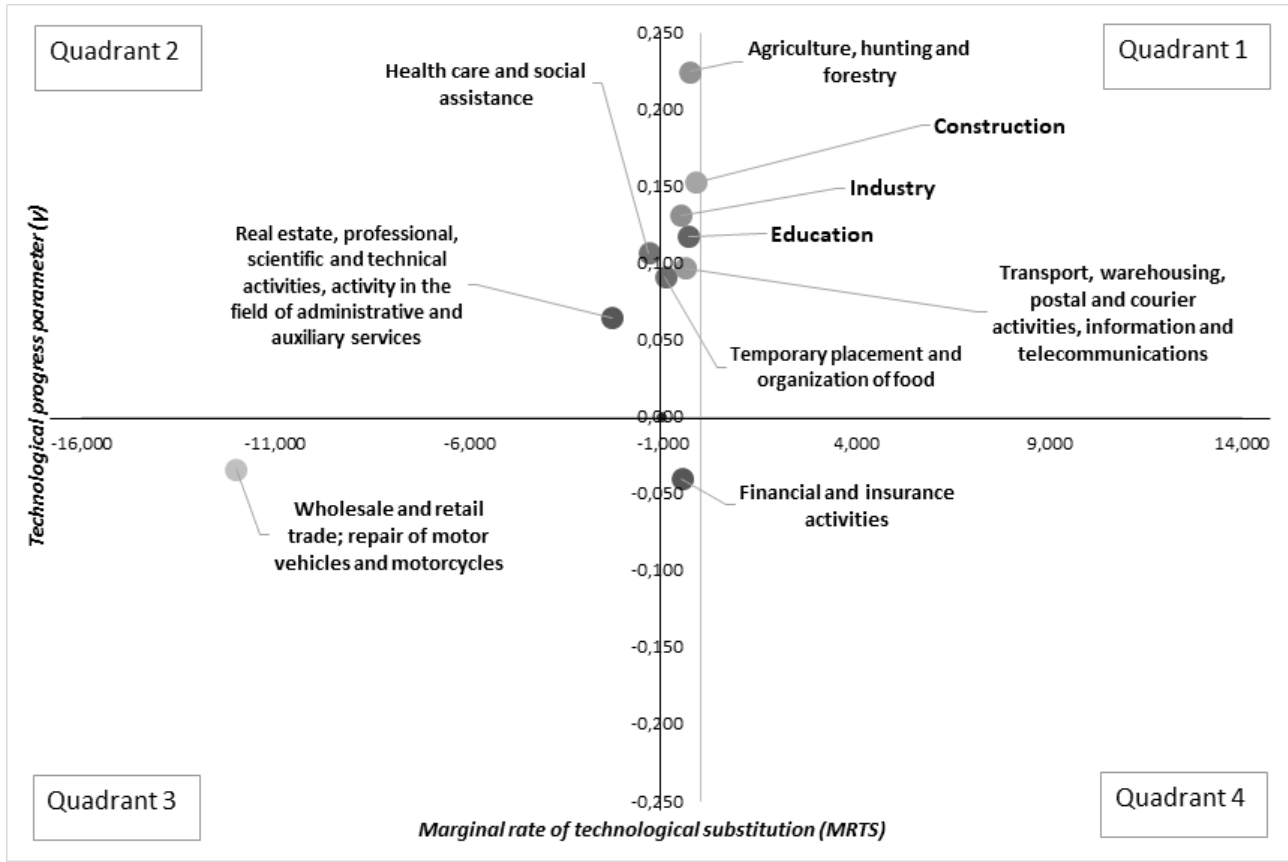

Fig. 1. Positioning of national economy sectors on matrix "Marginal rate of technical substitution and Technological progress parameter"

Data from fig. 1 show that quadrant 1 of the proposed matrix comprise 6 sectors of national economy, particularly: agriculture, hunting and forestry $(\gamma=0.225 ;$ MRTS $=-$ $0.293)$; construction $(\gamma=0.153 ; M R T S=-0.127)$; industry $(\gamma=0.131 ;$ MRTS $=-0.523)$; education $(\gamma=0.117 ;$ MRTS $=-$ $0.319)$; transport, warehousing, postal and courier activities, information and telecommunications $(\gamma=0.097$; MRTS $=-$ $0.412)$; temporary placement and organization of food $(\gamma=0.091 ; M R T S=-0.932)$. Innovation development of the national economy sectors, included to the quadrant 1 , are characterized by the compliance with technological progress, since technological progress parameter is $\gamma>0$, therefore agriculture, hunting and forestry turned out leader of the innovation development. Another peculiarity of the national economy sectors from quadrant 1 of matrix "Marginal rate of technical substitution and Technological progress parameter" is dominating of human capital over physical capital mostly in construction (substitution of 1 mln UAH of total assets is equal to 131 workers and vice versa - substitution of 1 thousand workers is equal to $7.7 \mathrm{mln}$ UAH of total assets), and the least - in the sector of temporary placement and organization of food (substitution of $1 \mathrm{mln}$ of total assets is equal to 932 workers and vice versa - substitution of 1 thousand workers is equal to $1.1 \mathrm{mln} \mathrm{UAH}$ of total assets).

Quadrant 2 of the matrix "Marginal rate of technical substitution and Technological progress parameter", which is characterized by compliance with technological progress and dominating of physical capital over human capital, comprises 2 sectors of national economy - health care and social assistance $(\gamma=0.107 ;$ MRTS $=-1.361$, i.e. to substitute $1 \mathrm{mln}$ $\mathrm{UAH}$ of total assets it is necessary to involve additionally 1361 persons, and to substitute 1 thousand workers it is necessary additionally to involve 735 thousand UAH of total assets); real estate, professional, scientific and technical activities, activity in administrative and auxiliary service $(\gamma=0.065 ; M R T S=-2.301$, i.e. to substitute $1 \mathrm{mln} \mathrm{UAH}$ of total assets it is necessary additionally to involve 2301 persons, and to substitute 1 thousand workers it is necessary additionally to involve 735 thousand UAH of total assets).

Sector of wholesale and retail trade, repair of motor vehicles and motorcycles $(\gamma=-0.034 ; M R T S=-12.038)$ is included to quadrant 3 in "Marginal rate of technical substitution and Technological progress parameter" matrix, and is characterized with lagging behind technological progress and dominating of physical capital over human capital (substitution of $1 \mathrm{mln}$ UAH of total assets is equal to 12038 persons, and substitution of 1 thousand workers is equal to 83 thousand UAH of total assets).

Financial and insurance activities sector $(\gamma=-0.040$; $M R T S=-0.500)$ is included to quadrant 4 in the matrix "Marginal rate of technical substitution and Technological progress parameter", innovation development of which is characterized by lagging behind the technological progress and dominating of human capital over physical capital, since 
substitution of $1 \mathrm{mln}$ of total assets is equal to 500 workers and, accordingly, substitution of 1 thousand workers is equal to $2 \mathrm{mln}$ of total assets value.

\section{CONCLUSION}

A general conclusion is made concerning the conceptual bases of optimization modeling of innovation processes at the branch level. It is shown that the sectoral transformation mechanisms by the impact of technological progress factor are intended to ensure transformation of the economic system. The proposed conceptual framework for modeling industry innovation processes is based on the fact that the task of innovation management is combinatorial, and its complexity increases with the increase in the number of projects or the planning horizon expansion. Therefore, to solve this problem, it is advisable to use algorithms that successfully work with big data, capable to solve the multicriteria problems and flexible to account the possible factors and criteria.

A key component of improved multiplicative dynamic model of $\mathbf{J}$. Tinbergen production function is technological progress parameter, which reflects the level of innovation development of national economy. In the course of the study, Tinbergen's production function equation for the Ukrainian industry was obtained. The equation obtained is reliable and statistically significant, as it is described by high statistical estimates. In conclusion suggestion is made that the given improved multiplicative dynamic model can be used for the composition of integrated indicator of innovation priority sector of the national economy. It is based on the use of standardized indicators and weighting coefficients of normalized indicator. The scheme of calculation of weighting coefficients for each index within the integral indicator of industrial production technological development level is proposed.

\section{ACKNOWLEDGMENT}

The publication was publicly funded by Ministry of Education and Science of Ukraine for developing of research project «Institutional and technological design of innovation networks for Ukraine national security systemic providing» and research project «Development of scientific and methodological foundations and practical tools for evaluating of the product innovations commercial (market) prospects».

\section{REFERENCES}

[1] J. Tinbergen, "On the theory of long-term economic growth," Weltwirtschaftliches Archiv, Vol. 10, pp. 511-549, 1942.

[2] R. Solow, "Technical change and the aggregate production function," The Review of Economics and Statistics, Vol. 39, Issue 3, pp. 312320, 1957.

[3] J. R. Moroney and C. E. Ferguson, "Efficient estimation of neoclassical parameters of substitution and biased technological progress," Southern Economic Journal, Vol. 37, No. 2, pp. 125-131, 1970.

[4] G. D. L. Faria and M. M. Andersen, "Sectoral dynamics and technological convergence: an evolutionary analysis of ecoinnovation in the automotive sector," Industry and Innovation, 24:8, pp. 837-857, 2017. DOI: 10.1080/13662716.2017.1319801

[5] N. Innocenti and L. Lazzeretti, "Do the creative industries support growth and innovation in the wider economy? Industry relatedness and employment growth in Italy," Industry and Innovation, 2019.
DOI: $10.1080 / 13662716.2018 .1561360$

[6] T.-A. Borgersen and R. M. King, "Industrial structure and jobless growth in transition economies," Post-Communist Economies, 28:4, pp. 520-536, 2016.

[7] J. Drucker, “An Evaluation of Competitive Industrial Structure and Regional Manufacturing Employment Change," Regional Studies, 49:9, pp. 1481-1496, 2015. DOI: 10.1080/00343404.2013.837874

[8] J. R. Burns and O. Ulgen, "A sector approach to the: formulation of system dynamics models," International Journal of Systems Science, 9:6, pp. 649-680, 1978. DOI: 10.1080/00207727808941727

[9] J. Aarstad and O. Kvitastein, "Enterprise R\&D investments, product innovation and the regional industry structure," Regional Studies, 2019. DOI: $10.1080 / 00343404.2019 .1624712$

[10] M. Shafieezadeh, M. K. Hormozi, E. Hassannayebi, L. Ahmadi, M. Soleymani, and A. Gholizad, "A system dynamics simulation model to evaluate project planning policies," International Journal of Modelling and Simulation, 2019. DOI: 10.1080/02286203.2019.1596779

[11] P. Bernal, P. Juan Maicas, and P. Vargas, "Exploration, exploitation and innovation performance: disentangling the evolution of industry," Industry and Innovation, 26:3, pp. 295-320, 2019. DOI: 10.1080/13662716.2018.1465813

[12] Ch.-J. Chen, B.-Wen Lin, Jun-Y. Lin, and Yung-Ch. Hsiao, "Technological diversity, knowledge flow and capacity, and industrial innovation," Technology Analysis \& Strategic Management, 30:12, pp. 1365-1377, 2018.

[13] M. Grillitsch \& B. Asheim, "Place-based innovation policy for industrial diversification in regions," European Planning Studies, 26:8, pp. 1638-1662, 2018. DOI: 10.1080/09654313.2018.1484892

[14] N. A. Kravchenko, S. A. Kuznetsova, and A. T. Yusupova, "Innovative offers in the mirror of industry trajectories," Innovations, vol. 4, pp. 31-37, 2006.

[15] O. Prokopenko, M. Slatvinskyi, N. Bikoshkurska, M. Biloshkurskyi, and V. Omelyanenko, "Methodology of national investment and innovation security analytics," Problems and Perspectives in Management, № 17 (1), pp. 380-394, 2019.

[16] T. V. Ponomarenko, O. V. Prokopenko, M. A. Slatvinskyi, N. V. Biloshkurska, M.V. Biloshkurskyi, and V.A. Omelyanenko, "National Investment and Innovation Security Assessment Methodology," International Journal of Mechanical Engineering and Technology, №10 (2), pp. 847-857, 2019.

[17] A.F., Shorikov, and V.A., Babenko, "Optimization of assured result in dynamical model of management of innovation process in the enterprise of agricultural production complex", Economy of Region, iss. 1, 2014, pp. 196-202. DOI: 10.17059/2014-1-18

[18] I., Wiebe, V., Oliinyk, and Y., Halynska, "Innovative instrument of collaborative alliance management in the "State-Region-Enterprise system of withdrawal of the rent income in the extracting industry," Marketing and Management of Innovations, iss. 2, 2018, pp. 247261. DOI: $10.21272 / \mathrm{mmi} .2018 .2-20$

[19] J. Tinbergen and D. Haag, "Exhaustion and technological development: a macro-dynamic policy mode," Zeitschrift für Nationalökonomie, Vol. 33, pp. 213-234, 1973.

[20] Volume of products (goods, services) sold by the economic entities by types of economic activity. Official site of the State Statistics Service of Ukraine. Available from: http://www.ukrstat.gov.ua/operativ/operativ2013/pr/orp_rik/orp_rik_u .htm

[21] Number of salaried workers at the economic entities by types of economic activity. Official site of the State Statistics Service of Ukraine. Available from: http://www.ukrstat.gov.ua/operativ/operativ2014/fin/osp/kzp/kzp_u/k zp_u_16.htm.

[22] Indicators balances of enterprises of economic activity. Official site of the State Statistics Service of Ukraine. Available from: http://www.ukrstat.gov.ua/operativ/operativ2017/fin/sbp/sbp_u/sbp_3 _17_u.htm.

[23] Classification of Types of Economic Activities of Ukraine (CTEA2010). Official site of the State Statistics Service of Ukraine. Available from: http://kved.ukrstat.gov.ua/KVED2010/kv10_i.html. 